\title{
THE ILLINOIS DOCTRINE OF INNOCENT CONSTRUCTION: A MINORITY OF ONE
}

One of the most troublesome problems facing the law of defamation is the choice of a standard by which to test ambiguous but allegedly defamatory publications. The most recent development in this area is the Illinois Supreme Court's approval of the so-called innocent construction rule, which has been successfully invoked in the courts of appeals and in federal courts applying Mllinois. Iaw for more than a decade.1

John v. Tribune Co. ${ }^{2}$ arose from two newspaper accounts of a police raid on a house of prostitution in Chicago. Details of the stories, apparently obtained by the newspaper from the police, included the information that Dorothy Clark, the suspected proprietor of the establishment, was fifty-seven years old and was also known as Dolores Reising, Eve Spiro and Eve John. ${ }^{3}$

' 1 Illinois courts: Judge v. Rockford Memorial Hosp., 17 III. App. 2d 365, 150 N.E.2d 202 (1958); Epton v. Vail, 2 IIl. App. 2d 287, 119 N.E.2d 410 (1954); Tiernan v. East Shore Newspapers, Inc., 1 IIl. App. 2d 150, 116 N.E.2d 896 (1953); Piacenti v. Williams Press, Inc., 347 IIl. App. 440, 107 N.E.2d 45 (1952); Eick v. Perk Dog Food Co., 347 III. App. 293, 106 N.E.2d 742 (1952); Parmelee v. Hearst Publishing Co., 341 Ill. App. 339, 93 N.E. 2d 512 (1950); Dilling v. Illinois Publishing \& Printing Co., 340 Ill. App. 303, 91 N.E.2d 635 (1950); Creitz v. Bennett, 273 Ill. App. 88 (1933); LaGrange Press v. Citizen Publishing Co., 252 Ill. App. 482 (1929); Fulrath v. Wolfe, 250 IIl. App. 130 (1928); Davis v. Ferguson, 246 IIl. App. 318 (1927); Young v. Richardson, 4 III. App. 364 (1879).

Federal courts applying Illinois law: Crosby v. Time, Inc., 254 F.2d 927 (7th Cir. 1958); Schy v. Hearst Publishing Co., 205 F.2d 750 (7th Cir. 1953); Brewer v. Hearst Publishing Co., 185 F.2d 846 (7th Cir. 1950).

Subsequent to the decision of the Illinois Supreme Court in John v. Tribune Co., 24 III. 2d 437, 181 N.E. 2d 105 (1962), the doctrine was applied in Porcella v. Time, Inc., 300 F.2d 162 (7th Cir. 1962).

224 III. 2d 437, 181 N.E.2d 105 (1962).

3 The first publication stated:

"Five women, one identified as a former girl friend of Tony Accardo, Capone gangster, were seized by vice squad police last night in a raid on a lavishly furnished nine-room apartment at 4417 Ellis Avenue.

"Detectives Jack Woessner, Edward Puhr, and Patrick Rafferty said they made the raid after an unnamed policemen paid a $\$ 100$ fee to one of the women to obtain evidence of prostitution in the apartment. Two men seized as they were entering the apartment were questioned and released.

"Dolores Reising, 57, alias Eve Spiro and Eve John, who, police said, was known years ago as Accardo's woman friend, was held as the suspected keeper of the apartment."

The second publication read:

"Five women arrested by Detectives Jack Woessner and Edward Puhr of Hyde Park Station in a vice raid at 4417 Ellis Ave. Saturday night will appear in Women's court Wednesday.

"Dorothy Clark, 57, who gave 4417 Ellis Ave. as her address, was charged with being keeper of a disorderly house and selling liquor without a license. Police said she also is known as Dolores Reising, Eve Spiro, and Eve John, and was known years ago as a girl friend of Tony Accardo, Capone gangster." 24 IIl. 2d at 439-40; 181 N.E.2d at 106. 
By virtue of one of the greatest coincidences 4 in a reported libel case there lived in the basement of the building a young woman whose maiden name was Eve Spiro, and whose name at the time was Eve John. The Illinois Supreme Court held that the "alias" names could not, as a matter of law, be read as the "target" names of the publication and therefore were not "of and concerning" the plaintiff. The court went on to observe:

We further believe the language in defendant's articles is not libelous of plaintiff when the innocent construction rule is consulted. That rule holds that the article is to be read as a whole and the words given their natural and obvious meaning, and requires that words allegedly libelous that are capable of being read innocently must be so read and declared nonactionable as a matter of law.... Since both of the publications here are capable of being construed as referring only to Dorothy Clark-Dolores Reising as the keeper of the disorderly house, they are innocent publications as to the plaintiff. 5

On at least two occasions rules similar to the one applied by the Illinois courts have been tried and rejected. Indeed, the innocent construction doctrine was renounced by the California Supreme Court only four years prior to the decision in John v. Tribune Co. ${ }^{6}$ This comment will examine the innocent construction doctrine in light of these past experiences and in light of the continuing need to develop better solutions to the dilemma of the ambiguous publication. The doctrine, though articulated in terms of liability theory, in reality involves the interrelationship between liability and damage presumptions. An examination of it will reveal the flux in the law created by tension between conventional liability and damage rules.

\section{I}

Most allegedly defamatory language is ambiguous. The problem of defining the appropriate standard for measuring objectionable language is therefore of

4 For another famous coincidence in libel law, see E. Hulton \& Co. v. Jones, [1910] A.C. 20. The article that brought about the suit is reported in the lower court's opinion. [1909] 2 K.B. 444, 445. It reads in part as follows:

"Whist! there is Artemus Jones with a woman who is not his wife, who must be, you know-the other thing!' whispers a fair neighbor of mine excitedly into her bosom friend's ear. Really, is it not surprising how certain of our fellow-countrymen behave when they come abroad? Who would suppose by his goings on, that he was a church warden at Peckham?"

The plaintiff was not a church warden at Peckham but a lawyer of North Wales who up to 1901 had contributed signed articles to defendant's newspaper. The House of Lords held that the article was of and concerning the plaintiff even though the defendant's correspondent had supposed he was using a fictitious name. In response to the appellant's argument that "the question is who was meant," Lord Loreburn replied: "Is it not rather who was hit?" [1910] A.C. at 22.

524 III. 2 d at 442-43, 181 N.E.2d at 108.

6 See pp. 537-38 infra. From the rather summary fashion in which John v. Tribume Co. gave its approval to the innocent construction doctrine, it would seem that the Illinois Court was not aware of the California court's decision. 
major significance. The question involves the scope of the jury's role in determining what is defamatory. In negligence suits the court can always take the case from the jury by holding that the defendant had no duty to the plaintiff; the desirability of according the court a similar power to control defamation actions by holding words non-actionable as a matter of law is the issue in the innocent construction cases. The general rule in defamation is that it is a question of law whether certain words are capable of a defamatory construction, and a question of fact whether they were understood in the defamatory sense. 7 There are various possible refinements to the rule: (1) Unless the court can say that the language is not reasonably capable of any defamatory meaning, the case must be submitted to the jury; (2) in order to establish a prima facie case the plaintiff must show that it was more likely than not that the ordinary reader would infer a defamatory meaning from the publication; (3) where language is susceptible of several possible meanings, the court will choose the one that makes it non-actionable and direct a verdict for the defendant; (4) where by any stretch of the imagination the court, or the defendant, can think of an innocent interpretation, the words are not actionable as a matter of law.

The prevailing approach is represented by the first of these standards. In direct contradiction to the position taken by John $v$. Tribune Co., the majority of jurisdictions hold that if language is susceptible of several meanings it is for the jury to determine the sense in which it was used and understood.8 However, occasional deviations from this formula suggest a lack of universal satisfaction. 9

7 Krebs v. McNeal, 222 Miss. 560, 76 So. 2d 693, (1955); Blanchard v. Claremont Eagle, 95 N.H. 375, 63 A.2d 791 (1949); McAndrew v. Scranton Republican Publishing Co., 364 Pa. 504, 72 A.2d 780 (1950); De Witte v. Kearney \& Trecker Corp., 265 Wis. 132, 60 N.W.2d 748 (1953).

8 Curtis Publishing Co. v. Vaughn, 278 F.2d 23 (D.C. Cir. 1960); Atlas Sewing Centers, Inc. v. National Ass'n of Independent Sewing Mach. Dealers, 260 F.2d 803 (10th Cir. 1958); McRae v. Afro-American Co., 172 F. Supp. 184 (E.D. Pa. 1959); Gearhart v. WSAZ, Inc., 150 F. Supp. 98 (E.D. Ky. 1957); Knapp v. Post Printing \& Publishing Co., 111 Colo. 492, 144 P.2d 981 (1943); Southeastern Newspapers, Inc. v. Walker, 76 Ga. App. 57, 44 S.E.2d 697 (1947); Mick v. American Dental Ass'n, 49 N.J. Super. 262, 139 A.2d 570 (1958); Nichols v. Item Publishers, Inc., 309 N.Y. 596, 132 N.E.2d 860 (1956); Pear1stein v. Draizin, 190 Misc. 27, 73 N.Y.S.2d 594 (Sup. Ct. 1947); Nettles v. MacMillan Petroleum Corp., 210 S.C. 200, 42 S.E.2d 57 (1947); Brodsky v. Journal Publishing Co., 73 S.D. 343, 42 N.W.2d 855 (1950); Langford v. Vanderbilt Univ., 199 Tenn. 389, 287 S.W.2d 32 (1956).

9 The most extreme deviation in the history of common law was the now dead doctrine of mitior sensus under which, if an allegedly slanderous utterance could be interpreted as having a "lenient sense," it had to be so interpreted as a matter of law. During the sixteenth and seventeenth centuries when mitior sensus flourished, the English courts went to ludicrous lengths to find a lenient sense in an alleged slander which was therefore non-actionable. The doctrine perhaps reached the height of its glory in the case of Holt v. Astrigg, Cro. Jac. 184, 79 Eng. Rep. 161 (1607), which has been commented on as follows:

"The defendant, in that case, had spoken words which, to the mind of anyone not crusad- 
It can be said that at the present time the complex and highly structured rules of defamation evince a pro-plaintiff bias. Although truth is a defense to libel and slander actions, the presumption that an allegedly defamatory publication is false is almost impossible to rebut in some instances.10 Malice, which is said to be the gist of the action for defamation, is irrebuttably presumed.11 Finally, even though the defendant's conduct in given circumstances is completely innocent, the defendant is liable if the plaintiff is damaged. If the publication is written or if the alleged harm falls within one of the slander per se categories damage is presumed.12

Most pertinent of the aforementioned rules to the present discussion is the doctrine of absolute liability. It may seem anomalous that a system in which tort liability is keyed to the negligence principle should carve out one area of liability without fault. Professor Morris suggests that non-negligent newspaper libel seldom occurs and that "by holding newspapers for all inadvertent libels, a small number of innocents may be hurt but a large number of guilty are brought to surer justice."13 This is small consolation, however, to the "small number of innocents," and some states, whether or not in conscious reaction to the results of the principle of absolute liability, have ameliorated its harshness. For example, a number of state legislatures have enacted statutes restricting plaintiffs' recovery in a libel action to actual damages unless he gives notice to the libeler who refuses to publish a retraction. ${ }^{14}$ Although several of these retraction statutes have been held violative of the

ing under the banner of the Sensus Mitior, most clearly imputed murder. 'Sir Thomas Holt struck his cook on the head with a cleaver, and cleaved his head, the one part lying on the one shoulder, and another part on the other.' One would suppose that no construction of these words could in the wildest flight of imagination be suggested, which would be 'benignant' enough to bring back to life the slaughtered cook, or to admit of the defendant's escape on the ground that no crime, but only an actionable trespass, was imputed to the master. But such a suggestion was made, and, more, it prevailed. Judgment for the plaintiff was arrested, 'for it was not averred that the cook was killed, but argumentative'; and 'slander ought to be direct, against which there may not be any intendment, but here, notwithstanding such wounding, the party may yet be living, and it is then but trespass!' In other words, the defendant may have meant no more than that Sir John Holt had subjected his cook to temporary inconvenience and had taken an unwarrantable liberty with a part of his property by sundering it in twain, for which act the cook, on recovering from his shoulders and reuniting the undivided moities of his cleft skull, might sue his master in trespass. Bower, The Law of Actionable Defamation 334 (1908). (Emphasis in original.)

10 Consider, for example, the difficulty of proving the truth of a statement that a professional person is incompetent. Fitzgerald v. Young, 89 Neb. 693, 132 N.W. 127 (1911) (teacher); Ellsworth v. Martindale-Hubbell Law Directory, Inc., 68 N.D. 425, 280 N.W. 879 (1938) (lawyer).

11 Bromage v. Prosser, 4 B. \& C. 247, 107 Eng. Rep. 1051 (1825).

12 Remington v. Bentley, 88 F. Supp. 166 (S.D.N.Y. 1949); Thorley v. Lord Kerry, 4 Taunt. 355, 128 Eng. Rep. 367 (1812).

13 MORRIS, STUdIES IN THE LAW OF TORTS 316 (1952).

14 See, e.g., Cal. Civ. Code § 48a; OrE. Rev. STat. §§ 30.155-.175 (1961). 
fourteenth amendment for depriving an individual of his right to protect his reputation, 15 others have been upheld against constitutional objections. 16

A more frequent approach is judicial manipulation of the standard for interpreting ambiguous publications. Notable in this regard is the libel per se 'doctrine, which requires that special damages be proved if the defamatory meaning does not appear without resort to extrinsic facts. Thus, in the wellknown case of Shaw Cleaners \& Dyers v. Des Moines Dress Club $b^{17}$ the defendant cleaning establishment had run an advertisement stating that "when you buy cleaning for half price you get just what you pay for . . . halfway cleaning and pressing. Des Moines Dress Club prices are the lowest at which first quality workmanship can be produced." 18 At the time of this advertisement, and for several weeks previously, the plaintiff, a competitor, had been advertising a cleaning sale using the phrase, "half price for the second garment."19 The Iowa Supreme Court held:

In determining whether language is libelous per se, it must be viewed stripped of any pleaded innuendo. The meaning of the phrase "per se" is "taken alone, in itself, by itself." Words which are libelous per se do not need an innuendo, and, conversely, words which need an innuendo are not libelous per se.... Therefore, the alleged libelous language contained in the petition is not libelous or actionable per se, and the demurrer was rightly sustained unless by reason of the additional matters contained in the amendment to the petition, the plaintiff is entitled to recover special damages. 20

The libel per se doctrine has been discussed quite extensively and quite critically. 21 Most of the commentators have attributed the doctrine to judicial error and have advocated its demise. 22 Notwithstanding its possible accidental genesis, the doctrine should not be abolished if it serves the useful purpose of controlling certain types of ambiguous defamation cases. The present discussion will examine this unjustly maligned doctrine in the context of this utilitarian function.

The harshest effects of absolute liability for defamatory publications occur

15 Hanson v. Krehbiel, 68 Kan. 670, 75 Pac. 1041 (1904); Park v. Detroit Free Press Co., 72 Mich. 560, 40 N.W. 731 (1888); Byers v. Meridian Printing Co., 84 Ohio St. 408, 95 N.E. 917 (1911).

16 Werner v. Southern California Associated Newspapers, 35 Cal. 2d 121, 216 P.2d 825 (1950), appeal dismissed, 340 U.S. 910 (1951); Holden v. Pioneer Broadcasting Co., 228 Ore. 405,365 P.2d 845 (1961).

17215 Iowa 1130, 245 N.W. 231 (1932).

19 Id. at 1132, 245 N.W. at 232.

$18 \mathrm{Id}$. at 1131,245 N.W. at 232.

20 Id. at 1135-37, 245 N.W. at 233-34.

21 Seelman, The Law of LIBel AND Sl.ANDER IN New YORK ch. 2 (1941); Carpenter, Libel Per Se in California and Some Other States, 17 So. CAL. L. REv, 347 (1944); Isham, Libel Per Se and Libel Per Quod in Ohio, 15 OHo ST. L.J. 303 (1954); Developments in the Law-Defamation, 69 HARV. L. REV. 875, 889 (1956).

22 See, e.g., SEelmaN, op. cit. supra note 21, at 34; Carpenter, supra note 21. 
where a seemingly innocent statement becomes actionable because of some fact of which the publisher could not reasonably be expected to know. In Cassidy v. Daily Newspapers, Ltd.,23 a rather adventuresome Englishman known at some times as Mr. Cassidy and at others as Mr. Corrigan posed with a lady and was photographed at a horse race. The gentleman with the twin appellation informed the photographer that he was engaged to marry the lady and gave his permission to make the announcement. The photograph was accordingly published in the defendant newspaper with the inscription: "Mr. M. Corrigan, the race horse owner, and Miss X, [the Court omitted the lady's name] whose engagement has been announced." 24 What the newspaper did not print, and indeed did not know, was that the man was already married. 25 Mrs. Cassidy-Corrigan was somewhat upset by the whole affair, as was the newspaper when the Court of Appeal awarded her a $£ 500$ libel judgment. What could seem more innocuous than the simple announcement of an engagement, especially when the principals to it had given their consent? Yet out of this announcement grew a successful libel suit by a woman who was not mentioned in the publication and of whose very existence the defendant was unaware.

Regardless of whether the libel per se doctrine was born of judicial error, the rule has the effect of ameliorating the doctrine of absolute liability in those areas where its results would be most harsh. Lord Scrutton to the contrary notwithstanding, it is hardly reasonable to demand that news media investigate all possible facts about every individual whose name appears in their publications. In the case of a newspaper, whose worth derives chiefly from the currentness of its news, the delay accruing from such an investigation would destroy the value of the publication. To a large extent the libel per se doctrine frees the publisher from having to choose between the cost and delay of extensive investigation, on the one hand, and the burden of playing the dual role of news disseminator and insurance company, on the other. However, the rule need not preclude recovery by an injured plaintiff, for it merely conditions his recovery on proof that he was in fact damaged by the publication.

Some courts have recognized the value of the libel per se doctrine as a means of tempering the absolute liability principle. In MacLeod v. Tribune Publishing Co.,26 Mr. Justice Traynor said:

The purpose of the rule requiring proof of special damages when the defamatory meaning does not appear on the face of the language used is

23 [1929] 2 K.B. 331.

24 Id. at 337.

25 Lord Scutton's opinion, however, argues that it should have ascertained beforehand his marital status. The opinion states: "If publishers of newspapers, who have no more rights than private persons, publish statements which may be defamatory of other people, without inquiry as to their truth, in order to make their paper attractive, they must take the consequences, if on subsequent inquiry, their statements are found to be untrue or capable of defamatory and unjustifiable inferences." Id. at 341-42.

2652 Cal. 2d 536, 343 P.2d 36 (1959). 
to protect publishers who make statements innocent in themselves that are defamatory only because of extrinsic facts known to the reader. For example, a newspaper might erroneously report that "Mrs. A gave birth to a child last night." Mrs. A has been married only a month. The language used will take on a defamatory meaning only to those who know when Mrs. A was married, and many of them will also know that the paper made a mistake. In such a case, general damages for loss of reputation may be trivial, and the paper's mistake may have been innocent, for the content of its report would not alert it to the possibility of defamation. It is not unreasonable therefore to require proof of special damages to establish a cause of action. 27

III

Against this background the Illinois doctrine of innocent construction may be examined as a further attempt by the judiciary to solve the dilemma of the ambiguous publication.

Under the rule announced in John v. Tribune Co. a publication susceptible of an innocent interpretation is held to be non-defamatory as a matter of law. The court did not deal with the vexing question of whether words that are not defamatory are nonetheless actionable if the plaintiff can show special damages. The question really goes to the purpose of the defamation standard. If its purpose is to require a showing that the words as published possess a minimum tendency to hold the plaintiff up to hatred, ridicule, contempt or obloquy, failure to meet this minimum standard could not be cured by proof of special damages. On the other hand, if the purpose of the standard is simply to establish a basis from which the inference of general damages may be drawn, words that in fact cause damage would be objectionable regardless of their lack of defamatory character.

The solution of the problem would seem easier in a jurisdiction that adheres to the innocent construction doctrine. A rule that selects from all possible meanings that which will deny recovery is open to the objection that some wronged plaintiffs will be left without a remedy. It would appear proper to send a plaintiff's case to the jury, where special damages are shown, even though the defendant's publication is capable of an innocent construction. The Illinois courts have not considered this question directly, but language in at least one opinion indicates that a plaintiff may nullify the effect of the doctrine by proof of special damages. 28 If this dictum represents the law, the doctrine is not a direct manipulation of defamation liability but rather of the damage presumption of liability.

27 Id. at 550, 343 P.2d at $43-44$.

28 In Eick v. Perk Dog Food, 347 IIl. App. 293, 306, 106 N.E.2d 742, 748 (1952), the Illinois Appellate Court said: "Where allegedly libelous matter is ambiguous, the court will interpret the matter innocently, if possible.... Plaintiff's claim that the advertisements were libelous on their face cannot stand. Defendants' actions were not such that this court will presume damage to plaintiff's reputation without any showing of special damages." 
The scope of the innocent construction doctrine is considerably broader than that of libel per se. The latter doctrine applies only where the ambiguity results from the circumstance that the statement is innocent on its face but libelous in light of other facts; the former rule applies to all ambiguous language. The innocent construction doctrine therefore gives the courts considerably more control over defamation actions than does libel per se. Indeed if literally applied, it would seem practically to eliminate the jury from the determination of the defamatory quality of ambiguous language. If the words are capable of an innocent construction, the defendant is entitled to a directed verdict. If there is no innocent construction that can be derived from the publication then there is no question of fact as to its defamatory character, and it should be declared defamatory as a matter of law. 29 Either way there would be no question to be submitted to the jury.

The approaches of the innocent construction and libel per se doctrines are entirely different, but within the limited scope of the latter, the result may be the same if the innocent construction doctrine merely relegates the plaintiff to proof of special damages. The innocent construction doctrine would deal with the problem of the publication whose defamatory meaning appears only by reference to extrinsic fact by holding as a matter of law that the innocent meaning, which does not consider the extrinsic fact, is the true meaning. The libel per se rule requires the plaintiff who must resort to innuendo to prove the defamatory quality of the publication to forfeit the damage presumption otherwise afforded. In either case the net effect is that the plaintiff can avoid a directed verdict for the defendant only by proving special damages. This similarity lends further support to the proposition that libel per se is more than a legal fluke. The development of two doctrines with a similar net effect suggests dissatisfaction with the area of the law in which those doctrines operate. 30

The fact that the Illinois appellate courts have not consistently applied the innocent construction doctrine to every appropriate case supports the view that it is a judicial tool to be used only when necessary. 31 In some cases it has been employed only as an alternative ground for denying recovery. For example, the cases holding that publications impugning the ability and qualifica-

29 In Brewer v. Hearst Publishing Co., 185 F.2d 846, 850 (7th Cir. 1950), the Seventh Circuit declared that under the law of Illinois "if the words are unambiguous and incapable of an innocent meaning they may be declared libelous as a matter of law." (Emphasis in original.)

30 There have been cases in jurisdictions recognizing both the innocent construction and the libel per se doctrines in which the courts have seemed unsure as to which of the two constituted the true basis of the decision. See Peabody v. Barham, 52 Cal. App. 2d 581, 126 P.2d 668 (1942); Fulrath v: Wolfe, 250 IIl. App. 130 (1928).

31 See, e.g., the lower court decisions in John v. Tribune, 28 III. App. 2d 300, 171 N.E.2d 432 (1960); 19 Ill. App. 2d 547, 154 N.E.2d 862 (1958). See also Ogren v. Rockford Star Printing Co., 288 IIl. 405,123 N.E. 587 (1919); Cook v. East Shore Newspapers, Inc., 327 III. App. 559, 64 N.E.2d 751 (1945). 
tions of a candidate for office were non-actionable because of the innocent construction rule have also held them subject to the privilege of fair comment.32

The more interesting decisions involve the sole issue of the meaning to be ascribed to the publication. The Illinois innocent construction doctrine has been applied to at least three types of recurring problems arising from the ambiguous nature of most defamatory statements. These problems are: (1) whether it is actionable to ascribe to the plaintiff membership in or sympathy with a group whose views are disapproved by the majority of the community; (2) whether a publication libelous of a group sufficiently identifies the plaintiff to allow him to recover; and (3) whether the principle of absolute liability should be extended to cases in which the statement is a true report of a news item, which has the unintended effect of defaming the plaintiff.

(1) The first problem reveals the dual level of the inquiry involved in all defamation cases. The initial question is whether the meaning ascribed to the language by the plaintiff, considered in a present-day context, is degrading enough to hold him up to hatred, ridicule or contempt. The second question, assuming that the first is answered in the affirmative, is whether the words used actually convey the meaning alleged by the plaintiff. Inherent in the first of these inquiries is the proposition that the actionable quality of words may vary with the era in which they were spoken. In 1919, when public feeling against socialists ran so high that several members of the New York state legislature, duly elected on the socialist ticket, were expelled despite the protest of Charles Evans Hughes and others, it was held libelous to say that a man was a socialist. 33 Similar words would probably not be actionable today. ${ }^{34}$ At one time it was not libellous to call someone a communist; 35 today such a charge is actionable. ${ }^{36}$ Thus, both Illinois cases which have applied the innocent construction rule to suits arising out of alleged imputation of communist sympathy denied recovery not because of failure to allege a libellous act, but because the publication was reasonably susceptible of an interpretation not ascribing communist leanings to the plaintiff. 'In Dilling $v$. Illinois Publishing \& Printing Co.,37 the defendant published an article which reported that the plaintiff and seven other individuals had been condemned by an

32 Judge v. Rockford Memorial Hosp., 17 Ill. App. 2d 365, 150 N.E.2d 202 (1958); Tiernan v. East Shore Newspajers, Inc., 1 Ill. App. 2d 150, 116 N.E.2d 896 (1953); Davis v. Ferguson, 246 Ill. App. 318 (1927).

.. 33 Ogren v. Rockford Star Printing Co., 288 III. 405, 123 N.E. 587 (1919).

34 See 33 Ill. LAW and PRActice, Slander and Libel \$22 n.8 (1958); Yankwich, Recent Developments in the Law of Creation, Expression, and Communication of Ideas, 48 Nw. U.L. REv. 543, 547 (1953).

35 Garriga v. Ríchfield, 20 N.Y.S.2d 544, 174 Misc. 315 (Sup. Ct. 1940).

36 Utah State Farm Bureau Fed'n v. National Farmers Union Serv. Corp., 198 F.2d 20 (10th Cir. 1952); Wright v. Farm Journal, 158 F.2d 976 (2d Cir. 1947); Mosler v. Whelan, 48 N.J. Super. 491, 138 A.2d 559 (1958).

37340 IIl. App. 303, 91 N.E.2d 635 (1950). 
American Legion resolution as "fostering subversive activities." 38 The article also reported the language of the resolution which charged that "Communists and Fascists continue to threaten our cherished ideals of Americanism."'39 In sustaining the defendant's motion to dismiss, the appellate court stated:

Words alleged to be libellous will receive an innocent construction if they are reasonably susceptible of it.... Nowhere in the article complained of is there a statement that plaintiff is a Communist or a Fascist or that she is an adherent of Communism or Fascism. All the article says about the plaintiff is that she is named in the resolution as one who is fostering subversive activities. 40

Parmelee v. Hearst Publishing Co., 41 involved a libel action based upon an article $^{42}$ stating that the plaintiff, a noted author and authority in economics and other social sciences, was part of the "strange company" kept by Henry Wallace. In a later part the article referred to the "wild people who wormed their way into the government... including many of the most malignant Communists in the world...."43 The court reiterated the innocent construction rule but apparently felt that its judgment for defendant was indicated even in the absence of such a doctrine. The opinion states that "no ordinarily reasonable reader could understand the language used to mean that plaintiff was a Communist." 44

(2) A statement directed at a group may provide the basis of a defamation action by a member of the group if the group is sufficiently small so that the reader could reasonably identify the individual as one of the group. In NiemanMarcus v. Lait, 45 groups of employees working at a Dallas department store brought an action against the authors of U.S.A. Confidential for assertions that some of the store's models and salesgirls were also operating as "cail girls" and that most of the salesmen were homosexuals. The store employed nine models, twenty-five salesmen and 382 saleswomen; 46 only the saleswomen were held not to have a cause of action. 47

The extent to which the innocent construction doctrine could modify the traditional principles governing defendant's freedom from suit by an individu-

${ }^{38}$ The article read in part: "Persons named in the resolution as fostering subversive activities were: Gerald L. K. Smith, Gerhardt Eisler, Elizabeth Dilling, William Z. Foster, Charles B. Hudson, Eugene Dennis, Leon de Aryan and Gerald D. Winrod." Id. at 304, 91 N.E.2d at 636.

${ }^{39} \mathrm{Id}$. at 305, 91 N.E.2d at 636.

$40 I d$ at 306,91 N.E.2d at 637.

41341 Ill. App. 339, 93 N.E.2d 512 (1950).

42 The article was written by a frequent defendant in defamation cases, Westbrook Pegler. See, e.g., Spanel v. Pegler, 166 F.2d 298 (2d Cir. 1948); Reynolds v. Pegler, 123 F. Supp. 36 (S.D.N.Y. 1954).

43341 III. App. at 344, 93 N.E.2d at 514.

44 Id. at 345, 93 N.E.2d at 514.

46 Id. at 313.

4513 F.R.D. 311 (S.D.N.Y. 1952).

47 Id. at 317. 
al member of a defamed group was indicated by dictum in Crosby v. Time, Inc. ${ }^{48}$ The defendant magazine in that case had stated that:

[T]op Western officials of the International Brotherhood of Teamsters were conspiring with Seattle gamblers to 1) control Portland's law enforcement agencies, 2) organize all the city's rackets, from pinball machines to prostitution. 49

With regard to the plaintiff the last paragraph of the article asserted that:

Mayor Peterson confirmed the charge. The Oregon Teamsters' representative, Clyde Crosby-whom the Oregonian revealed as an ex-convictadmitted that he had tried to get the mayor to fire Police Chief Jim Purcell, but only, he said, because the chief was in cahoots with Racketeer Elkins. 50

The Seventh Circuit held that no reader could have inferred that the plaintiff was one of the "top officials" assailed in the article and added the further observation that "even though it be assumed ... that he was one of such top officials, he could not prevail, under Illinois law, in the absence of a showing that all of such officials were accused of wrongdoing."51 A literal application of this dictum would eliminate the group libel problem by denying recovery in every case. If all members are shown to have been included then there is no problem of sufficiently identifying a particular plaintiff with the group. If all members are not included, none can recover. The innocent construction doctrine is of course capable of supporting the solution suggested by the Crosby case. 52 The article in Nieman-Marcus, for example, referred to "some" of the models and "most" of the salesmen, thus dividing both groups into those who did and those who did not engage in immoral activities. In a suit by any given plaintiff there are two constructions to which the publication is reasonably susceptible: The plaintiff either is a member of the defamed segment of the group or he is not. Since the innocent meaning must be chosen as a matter of law, the suit would be dismissed. It is doubtful that the Illinois courts will ever reach such a result; although technically within the purview of the innocent construction rule, that approach would deny recovery to all individuals even though by hypothesis some were defamed.

(3) The problem presented by language which the defendant reasonably assumes to be innocent but which turns out to be defamatory because of some extrinsic fact of which he was not aware has already been discussed. A similar problem arises when a report is made that $A$ has engaged in certain activities, and the language of the report unintentionally applies to $B$ as well as to $A$ because of their similar names. As to $A$ the report is true and consequently non-actionable. As to $B$ the law faced a dilemma: Either the innocent plaintiff

48254 F.2d 927 (7th Cir. 1958).

$49 \mathrm{Id}$. at 928.

52 It is not entirely clear that the Crosby dictum rests on the innocent construction doctrine, but it is difficult to see what other "Dlinois law" would support the conclusion. so Id. at 928-29.

$51 \mathrm{Id}$. at 930 . 
must be denied recompense for the harm he has suffered or the innocent defendant must pay for defaming one whom he not only did not intend to defame but who he did not even know existed. The dilemma appears to have been resolved in favor of the plaintiff in one leading case, the rule being that: "The question is not so much who was aimed at as who was hit." 53

Publishers have generally been successful in avoiding the effects of the unknown plaintiff's absolute right of recovery by reporting not only names but also addresses. Such a precaution is not one hundred per cent effective. In John v. Tribune Co. there were not simply two persons living at the same address with the same names; the proprietor of the house of prostitution, who was the intended subject of the report, had been known by both the maiden name and the married name of the plaintiff who lived at the same address. A more adequate hypothetical with which to question the propriety of absolute liability for verbal conduct could scarcely be imagined. The effect of the application of the innocent construction doctrine to the case was to bring the law of defamation into line with the generally prevailing Anglo-American tort principle of no liability without fault. In Illinois, it now matters who was aimed at.

\section{III}

The innocent construction doctrine had a short but interesting existence in California. Its beginning can be traced to Peabody v. Barham, 54 in which the columns of a widely circulated daily published the statement that "Eddie Peabody's divorcing wife, ten years his senior, is also his aunt." 55 Relying for its authority on a single case which mentions but does not follow the innocent construction rule, 56 the court announced a rule which appears to combine elements of both libel per se and innocent construction. 57 The rationale for the decision, however, is clearly not libel per se, since the opinion does not look to the effect of extrinsic facts on the actionable nature of the words. The

53 Corrigan v. Bobbs-Merrill Co., 228 N.Y. 58, 64, 126 N.E. 260, 262 (1920). The general applicability of the rule stated in the $B o b b s-M e r r i l l$ case is not entirely clear. The case involved the liability of a publishing house for the defamatory content of a book it had published. The publishing house may not have intended to defame the plaintiff, but the author of the book probably did. The situation in which reference to the plaintiff is purely accidental is somewhat different. However, E. Hulton \& Co. v. Jones, [1910] A.C. 20, see note 4 supra, which seems to hold the defendant absolutely liable in all cases in which the publication refers to the plaintiff, probably represents the law of the United States as well as that of England.

5452 Cal. App. 2d 581, 126 P.2d 668 (1942).

55 Id. at 583,126 P.2d at 669.

56 Dillard v. Shattuck, 36 N.M. 202, 11 P.2d 543 (1932).

57 The opinion declares: "When offending language is susceptible of an innocent interpretation it is not actionable per se. Neither will language be given a libelous character unless such is its plain and obvious import. ... [Citing Dillar v. Shattuck, supra note 56.] Neither is it actionable per se if the offending language has more than one meaning." $52 \mathrm{Cal}$. App. 2d at 584, 126 P.2d at 670. 
reasoning of the Peabody case is a classic illustration of the results of carrying the innocent construction rule to its extreme. The average reader might of course agree with the plaintiff that the words charged him with the crime of incestuous marriage. However, this was not the only possible interpretation: The woman referred to in the publication might be the plaintiff's aunt because of a former marriage to his consanguineous uncle. The innocent interpretation prevailed as a matter of law, and judgment was entered for the defendant.

In Babcock v. McClatchy Newspapers 58 the defendant newspaper carried the following challenge made by a candidate for the office of district attorney to his opponent: "The people of this county have a right to ask: 1 . How was it possible for you, Mr. Babcock, going into office dead broke, on a salary of $\$ 4500$ to buy an office building at a purported price of $\$ 80,000$ ?" 59 The court conceded that the publication was "open to the construction that dishonesty and corruption may be inferred,"60 but held that it was also capable of an innocent construction and therefore was non-actionable. There was nothing in the statement to negate the possibility that the plaintiff had obtained the money by gift, inheritance or profitable investment. 61

After the rather extreme results reached in Peabody and Babcock the decision in Menefee v. Codman 62 is somewhat surprising. In that case the plaintiff, a leading citizen of her community and a part-time newspaper woman and teacher complained of the publication of derogatory comments concerning her trip to Paris. The complaint asserted that the question "who covered Audrey while Audrey covered the water front?"63 was libelous. The court purported to apply the innocent construction doctrine but nevertheless upheld the plaintiff's verdict. The opinion states:

It is difficult to ascribe an innocent meaning to this publication. The use of the verb "cover" as meaning copulation is as indicated by the dictionary definition generally connected with the breeding of animals; it might be described as a barnyard colloquialism but appellant asserted that plain Audrey's trip to Europe was causing a lot of local yokel comment whenever mentioned and city folk often refer to the farm population as "local yokels." 64

The facts of the Menefee case illustrate a problem that courts rarely consider: What requirement is there that the words be understood in a defamatory sense by the audience to whom they are directed? Words spoken to the plaintiff in the presence of his small children who do not understand them, 65 or in a foreign language understood by the plaintiff but not by any bystanders ${ }^{66}$ have

5882 Cal. App. 2d 528, 186 P.2d 737 (1947).

59 Id. at 531, 186 P.2d at 738. $\quad 62155$ Cal. App. 2d 396, 317 P.2d 1032 (1957).

$60 \mathrm{Id}$. at 533, $186 \mathrm{P} .2 \mathrm{~d}$ at $740 . \quad 63 \mathrm{Id}$. at $400,317 \mathrm{P} .2 \mathrm{~d}$ at 1034.

$61 \mathrm{Id}$. at 534, $186 \mathrm{P} .2 \mathrm{~d}$ at $740 . \quad 64 \mathrm{Id}$. at $405,317 \mathrm{P.2d}$ at 1037.

65 Sullivan v. Sullivan, 48 Ill. App. 435 (1892).

66 Economopoulos v. A.G. Pollard Co., 218 Mass. 294, 105 N.E. 896 (1914). 
been held non-actionable because there was been no publication. However, once these threshold requirements relating to publication are satisfied the courts seem not to consider the probable impact of the language upon the audience. An understanding of the meaning of animal breeding terms, for example, is anything but widespread. The question "who covered Audrey while Audrey covered the waterfront?" is just as innocuous to one who is not familiar with breeding terms as if the words had been spoken in a foreign language. In both cases the audience lacks sufficient knowledge to infer a derogatory meaning from the words stated. It is true, as the court asserts, that this rather special meaning of "cover" could be ascertained by looking in the dictionary but few people are accustomed to consulting lexicographers to ascertain the meaning of such simple words.

A case such as Menefee would seem to present an ideal situation for the application of the innocent construction doctrine. It is not apparent that anyone in the audience had sufficient understanding to interpret the publication in its defamatory sense; the just result would be to condition the plaintiff's recovery on proof that someone did so understand it. A finding that the words were susceptible of an innocent interpretation would achieve this result, since it was clear from the time the doctrine was first announced in Peabody that proof of special damages would permit recovery in California in spite of the existence of an innocent meaning. 67

Seventeen years after its illegitimate birth in Peabody v. Barham the California innocent construction rule was laid to rest by $\mathrm{Mr}$. Justice Traynor in MacLeod v. Tribune Publishing Co.68 The opinion recognizes the propriety of the libel per se doctrine to limit the effects of absolute liability but argues that a rule such as innocent construction cannot be relied upon to accomplish the same purpose because of its almost unlimited possible scope of application. In continuing the discussion of the hypothetical case based on a newspaper report that "Mrs. A gave birth to a child last night," 69 the opinion states:

The case would be entirely different, however, if the paper reported that "Mrs. A, who was married last month, gave birth to a child last night." A charge of immoral conduct is apparent to all from the language used, and the paper knows and is fully warned of the defamatory implication. Under the rule of the Peabody case, however, it would escape liability unless special damages are proved, for the language does not exclude the innocent possibility that Mrs. A was widowed or divorced a few months before her recent marriage and that the child is that of her former husband.

67 See Peabody v. Barham, 52 Cal. App. 2d 581, 585, 126 P.2d 668, 670 (1942).

$6852 \mathrm{Cal} .2 \mathrm{~d} 536,343$ P.2d 36 (1959). The case has been noted with approval in 33 So. CAL. L. Rev. 88(1959); 12 STAN. L. Rev. 685(1960); and 7 U.C.L.A. L. Rev. 560(1960). Prior to the MacLeod decision the California innocent construction rule had been discussed by Spiegel, Defamation by Implication -In the Confidential Manner, 29 So. CAL. L. REv. 306 (1956).

${ }^{69}$ See note 27 supra and accompanying text. 
Such hair-splitting analysis of language has no place in the law of defamation, dealing as it does with the impact of communications between ordinary human beings .....It protects, not the innocent defamer whose words are libelous only because facts unknown to him, but the clever writer versed in the law of defamation who deliberately casts a grossly defamatory imputation in ambiguous language. 70

The Ohio Supreme Court has also recognized the innocent construction doctrine, apparently on the supposition that the Peabody case represented the prevailing view. Becker v. Toulmin 71 was a suit by a patent agent against his former employer arising out of information circulated among the plaintiff's professional colleagues that the defendant had found it desirable to terminate the plaintiff's employment. The court held that the publication was not libelous per se, since its defamatory meaning did not appear in the absence of innuendo, and special damages were not alleged. The opinion further observes that:

It is conceded that the strongest claim plaintiff in the present case can make is that, although the offending language is susceptible of an innocent interpretation, it is also susceptible of a libelous meaning. If such is the case, that language is not actionable per se. Peabody v. Barham, $52 \mathrm{Cal}$. App. 581, 126 P.(2d), 668.72

The Becker case has never been cited, and Peabody v. Barham, on which it relied, has been overruled; its force as an authority for the existence of the innocent construction rule in Ohio would therefore seem minimal.

\section{IV}

There are at least three problems inherent in the doctrine approved by the Illinois Supreme Court in John v. Tribune Co. First, since the doctrine covers much of the same ground as libel per se, the addition of another rule tends to make even more cumbersome an area of the law that is already far from clear and simple. This difficulty is not serious, however; in most cases the outcome will be the same under either rule since both render the general damage presumption inoperative.

Second, an occasional defendant may subvert the doctrine, using it as a legal shield behind which he may be protected from liability for any remarks he chooses to make so long as they are cast in ambiguous terms. The possibility of such subversion was apparently the chief reason for the rejection of the innocent construction doctrine by the California Supreme Court. To avoid these results it would seem proper to restrict the defendant's use of the doctrine to those cases in which his conduct was completely innocent. This would require him to show not only that the publication was reasonably susceptible

\footnotetext{
$7052 \mathrm{Cal} .2 \mathrm{~d}$ at $550-51,343 \mathrm{P} .2 \mathrm{~d}$ at 44.

71165 Ohio St. 549, 138 N.E.2d 391 (1956).

72 Id. at 557,138 N.E.2d at 398.
} 
of an innocent meaning, but also that the presence of a defamatory meaning was an unreasonable surprise to him. So applied, the innocent construction doctrine would simply amount to a sensible retreat from strict liability.

Finally, there is some doubt whether the doctrine can withstand the pressures exerted upon it by the adversary system. The rule is inherently expansible, and with the creative imagination of defense counsel more than willing to suggest possible innocent meanings, there may be a tendency to stretch the doctrine to such an extent that its results are more humorous than just. On at least two prior occasions this has happened and the judiciary has found it necessary to repudiate its own offspring.

The Illinois doctrine of innocent construction has not been carried to the extent of either the common-law rule of mitior sensus or the late California innocent construction rule. As long as the Illinois courts keep their doctrine within bounds there is every reason to believe that it can be a useful addition to the controlling principles of defamation law. In the realm of physical injury, Anglo-American tort law allows damages only if the defendant's conduct is blameworthy. It seems rather anomalous that when the conduct consists of words and the injury is to reputation or to the ego rather than to the body there should be such a complete shift away from the principle of no liability without fault. The innocent construction doctrine vests the court with the power to nullify the effect of this aberration, thereby bringing defamation law into harmony with the rest of the legal system. 